\title{
Kinetic Analysis of the Gas-Phase Reactions of Methacrolein with the OH Radical in the Presence of $\mathrm{NO}_{\mathrm{X}}$
}

\author{
André Silva Pimentel*, and Graciela Arbilla
}

Departamento de Físico-Química, Instituto de Química,

Universidade Federal do Rio de Janeiro, Centro de Tecnologia, Bloco A, Sala 408, Cidade Universitária, 21949-900 Rio de Janeiro - RJ, Brazil

\begin{abstract}
Um mecanismo explícito para a reação da metacroleína (MTA) com radicais $\mathrm{OH}$, numa mistura $\mathrm{NO}_{\mathrm{x}}$ - ar, foi simulado resolvendo as equações diferenciais ordinárias usando o método RungeKutta-4-semi-implícito. Os resultados simulados são consistentes com os dados experimentais publicados e o modelo explica as principais vias de reação para a oxidação da MTA com radicais $\mathrm{OH}$ na presença de $\mathrm{NO}_{\mathrm{x}}$ - ar. Usando uma análise dos autovetores e autovalores dos coeficientes de sensibilidade, para todas as espécies químicas envolvidas em diferentes tempos de reação, foi extraída informação cinética do sistema. Este método foi utilizado para reduzir o modelo cinético de forma objetiva. Foi utilizado, também, o método tradicional de análise de velocidade de produção (ROPA) para estudar a importância relativa das reações individuais. Usando a informação da análise de componente principal e da análise de velocidade de produção, foram identificadas as principais reações individuais.
\end{abstract}

An explicit chemical mechanism for the reaction of methacrolein (MTA) with OH radicals in $\mathrm{NO}_{\mathrm{x}}$-air systems, was simulated by solving the corresponding ordinary differential equations using Runge-Kutta-4-semi-implicit method. The simulated results are consistent with the published experimental data and the model accounts for all the major pathways by which MTA reacts in $\mathrm{NO}_{\mathrm{x}}$-air systems. An eigenvalue-eigenvector analysis is used to extract meaningful kinetic information from linear sensitivity coefficients computed for all species of the chemical mechanism at several time points. This method is used to get an objective condition for constructing a minimal reaction set. Also, a classic method called rate of production analysis (ROPA) was used for the study of the reactions relevance. Using the principal component information as well as the rate of production analysis the main paths of reaction are identified and discussed.

Keywords: principal component analysis, eigenvalue-eigenvector analysis, rate of production analysis, methacrolein

\section{Introduction}

Methacrolein is an $\alpha, \beta$-unsaturated aldehyde. It is produced in a significant yield from the gas-phase reactions of isoprene, a vegetative emission ${ }^{1-6}$, with $\mathrm{OH}$ radical in the presence of $\mathrm{NO}_{x}{ }^{7-10}$ and $\mathrm{O}_{3}{ }^{11-12}$. Since the emissions of isoprene may dominate over anthropogenic nonmethane emissions on regional and global scales ${ }^{13-15}$, a knowledge of the atmospheric chemistry of methacrolein is a necessary input into the chemical mechanism for the atmospheric photooxidation of isoprene for use in airshed computers models ${ }^{16-17}$. Under atmospheric conditions, the major loss process for methacrolein is calculated to occur by reaction with the $\mathrm{OH}$ radical ${ }^{18}$.
In this work, the gas-phase reactions of methacrolein (hereafter MTA, $\mathrm{CH}_{2}=\mathrm{C}\left(\mathrm{CH}_{3}\right) \mathrm{CHO}$ ) with $\mathrm{OH}$ radicals in $\mathrm{NO}_{\mathrm{x}}$-air systems are simulated and an eigenvalue-eigenvector analysis of the linear sensitivity coefficients, called Principal Component Analysis ${ }^{19}$, is used to assess the parameter-concentration interdependence and obtain a reduced mechanism.

Reaction rate analysis for complex kinetic systems includes the solution of a mathematical model, $i$. $e$., a set of coupled kinetic ordinary differential equations, the study of the effects of parameter changes on the results and the exploration of important reaction pathways ${ }^{19-25}$. This information is important to decide which reactions should be included in a atmospheric photochemical mechanism and, 
also, which reactions should be experimentally studied. A good mechanism should be as simple as possible and the number of its parameters and components should be minimum.

Only one experimental study has been conducted for the MTA reaction with $\mathrm{OH}$ radicals ${ }^{26}$. In this study the products of MTA oxidation were measured and identified, obtaining directly quantitative yields for hydroxyacetone $\left(\mathrm{HOCH}_{2} \mathrm{C}(\mathrm{O}) \mathrm{CH}_{3}\right)$, methylglyoxal $\left(\mathrm{CH}_{3} \mathrm{COCHO}\right)$, formaldehyde (HCHO) and peroxymethacryloyl nitrate (hereafter $\left.\mathrm{PMN}, \mathrm{CH}_{2}=\mathrm{C}\left(\mathrm{CH}_{3}\right) \mathrm{C}(\mathrm{O}) \mathrm{OONO}_{2}\right)$. The authors have also discussed and recommended a mechanism to represent the MTA + OH chemistry. Nevertheless, to our knowledge, the solution of kinetic differential equations and a sensitivity analysis of the mechanism have not been done up to now.
Since the calculated results from a deterministic model are strictly a function of its parameters and variables as time, temperature and pressure, in these simulations the initial conditions for the simulations were those of the experimental work ${ }^{26}$ in order to compare the calculated and laboratory smog chamber results.

\section{The Chemical Mechanism}

As experimentally determined ${ }^{26}$ MTA reacts essentially with $\mathrm{OH}$ radicals by $\mathrm{H}$-atom abstraction, with an overall rate constant of $3.35 \times 10^{-11} \mathrm{~cm}^{3}$ molecule $\mathrm{s}^{-1} \mathrm{~s}^{-1}$ at $298 \mathrm{~K}^{27}$.

The complete chemical mechanism is listed in Table 1. It includes 38 species and 50 reactions. It was proposed on the basis of previous mechanisms ${ }^{28,29}$ and of the known MTA $^{26}$ and PMN ${ }^{30}$ chemistry. Thermal rate constants were either taken from literature ${ }^{31-34}$ or estimated by comparison

Table 1. Chemical Mechanism for Gas-Phase Reactions of MTA with the OH Radical in the Presence of $\mathrm{NO}_{\mathrm{x}}$

\section{Reactions}

\#1) $\mathrm{HONO}+\mathrm{OH} \rightarrow \mathrm{H}_{2} \mathrm{O}+\mathrm{NO}_{2}$

\#2) $\mathrm{OH}+\mathrm{HNO}_{3} \rightarrow \mathrm{H}_{2} \mathrm{O}+\mathrm{NO}_{3}$

3) $\mathrm{NO}+\mathrm{OH} \rightarrow \mathrm{HONO}$

4) $\mathrm{OH}+\mathrm{NO}_{2} \rightarrow \mathrm{HNO}_{3}$

5) $\mathrm{HO}_{2}+\mathrm{NO} \rightarrow \mathrm{OH}+\mathrm{NO}_{2}$

6) $\mathrm{NO}+\mathrm{O}_{3} \rightarrow \mathrm{NO}_{2}+\mathrm{O}_{2}$

7) $\mathrm{NO}+\mathrm{NO}_{3} \rightarrow 2 \mathrm{NO}_{2}$

8) $\mathrm{NO}_{2}+\mathrm{O}_{3} \rightarrow \mathrm{NO}_{3}+\mathrm{O}_{2}$

9) $\mathrm{HONO}+h v \rightarrow \mathrm{OH}+\mathrm{NO}$

10) $\mathrm{NO}_{2}+h \mathrm{v}+\left(\mathrm{O}_{2}\right) \rightarrow \mathrm{NO}+\mathrm{O}_{3}$

11) $\mathrm{HCHO}+\mathrm{OH}+\left(\mathrm{O}_{2}\right) \rightarrow \mathrm{HO}_{2}+\mathrm{CO}+\mathrm{H}_{2} \mathrm{O}$

12) $\mathrm{CH}_{3} \mathrm{CHO}+\mathrm{OH}+\left(\mathrm{O}_{2}\right) \rightarrow \mathrm{CH}_{3} \mathrm{CO}_{3}+\mathrm{H}_{2} \mathrm{O}$

13) $\mathrm{CH}_{3} \mathrm{O}+\left(\mathrm{O}_{2}\right) \rightarrow \mathrm{HCHO}+\mathrm{HO}_{2}$

14) $\mathrm{CH}_{3} \mathrm{O}_{2}+\mathrm{NO} \rightarrow \mathrm{NO}_{2}+\mathrm{CH}_{3} \mathrm{O}$

15) $\mathrm{CH}_{3} \mathrm{CO}_{3}+\mathrm{NO}+\left(\mathrm{O}_{2}\right) \rightarrow \mathrm{NO}_{2}+\mathrm{CH}_{3} \mathrm{O}_{2}+\mathrm{CO}_{2}$

16) $\mathrm{CH}_{3} \mathrm{CO}_{3}+\mathrm{NO}_{2} \rightarrow \mathrm{CH}_{3} \mathrm{CO}_{3} \mathrm{NO}_{2}$

17) $\mathrm{CH}_{3} \mathrm{CO}_{3} \mathrm{NO}_{2} \rightarrow \mathrm{CH}_{3} \mathrm{CO}_{3}+\mathrm{NO}_{2}$

18) $\mathrm{CH}_{3} \mathrm{CH}_{2} \mathrm{O}+\mathrm{O}_{2} \rightarrow \mathrm{CH}_{3} \mathrm{CHO}+\mathrm{HO}_{2}$

19) $\mathrm{CH}_{3} \mathrm{CH}_{2} \mathrm{O}+\mathrm{NO} \rightarrow \mathrm{CH}_{3} \mathrm{CH}_{2} \mathrm{ONO}$

20) $\mathrm{CH}_{2}=\mathrm{C}\left(\mathrm{CH}_{3}\right) \mathrm{CHO}+\mathrm{OH}+\left(\mathrm{O}_{2}\right) \rightarrow 0.42 \mathrm{HOCH}_{2} \mathrm{C}\left(\mathrm{O}_{2}\right)\left(\mathrm{CH}_{3}\right) \mathrm{CHO}+$ $0.08 \mathrm{O}_{2} \mathrm{CH}_{2} \mathrm{C}(\mathrm{OH})\left(\mathrm{CH}_{3}\right) \mathrm{CHO}+0.50 \mathrm{CH}_{2}=\mathrm{C}\left(\mathrm{CH}_{3}\right) \mathrm{C}(\mathrm{O}) \mathrm{OO}+0.50 \mathrm{H}_{2} \mathrm{O}$

21) $\mathrm{HOCH}_{2} \mathrm{C}\left(\mathrm{O}_{2}\right)\left(\mathrm{CH}_{3}\right) \mathrm{CHO}+\mathrm{NO} \rightarrow \mathrm{HOCH}_{2} \mathrm{C}(\mathrm{O})\left(\mathrm{CH}_{3}\right) \mathrm{CHO}+\mathrm{NO}_{2}$

22) $\mathrm{HOCH}_{2} \mathrm{C}(\mathrm{O})\left(\mathrm{CH}_{3}\right) \mathrm{CHO}+\left(\mathrm{O}_{2}\right) \rightarrow \mathrm{HOCH}_{2} \mathrm{C}(\mathrm{O}) \mathrm{CH}_{3}+\mathrm{CO}+\mathrm{HO}_{2}$

23) $\mathrm{O}_{2} \mathrm{CH}_{2} \mathrm{C}(\mathrm{OH})\left(\mathrm{CH}_{3}\right) \mathrm{CHO}+\mathrm{NO} \rightarrow \mathrm{OCH}_{2} \mathrm{C}(\mathrm{OH})\left(\mathrm{CH}_{3}\right) \mathrm{CHO}+\mathrm{NO}_{2}$

24) $\mathrm{OCH}_{2} \mathrm{C}(\mathrm{OH})\left(\mathrm{CH}_{3}\right) \mathrm{CHO} \rightarrow \mathrm{HCHO}+\mathrm{CH}_{3} \mathrm{C}(\mathrm{OH}) \mathrm{CHO}$
Rate Constants at $298 \mathrm{~K}$ Units of molecule, $\mathrm{cm}^{3}, \mathrm{~s}$

$$
\begin{aligned}
& \mathrm{k}_{1}=4.86 \times 10^{-12} \\
& \mathrm{k}_{2}=1.50 \times 10^{-13} \\
& \mathrm{k}_{3}{ }^{\mathrm{a}}=1.12 \times 10^{-11} \\
& \mathrm{k}_{4}^{\mathrm{a}}=1.34 \times 10^{-11} \\
& \mathrm{k}_{5}=8.28 \times 10^{-12} \\
& \mathrm{k}_{6}=1.81 \times 10^{-14} \\
& \mathrm{k}_{7}=2.60 \times 10^{-11} \\
& \mathrm{k}_{8}=3.23 \times 10^{-17} \\
& \mathrm{j}_{9}=1.63 \times 10^{-3} \\
& \mathrm{j}_{10}=4.26 \times 10^{-3} \\
& \mathrm{k}_{11}=9.57 \times 10^{-12} \\
& \mathrm{k}_{12}=1.58 \times 10^{-11} \\
& \mathrm{k}_{13}=4.59 \times 10^{4} \\
& \mathrm{k}_{14}=7.68 \times 10^{-12} \\
& \mathrm{k}_{15}{ }^{\mathrm{a}}=9.98 \times 10^{-12} \\
& \mathrm{k}_{16}=3.63 \times 10^{-12} \\
& \mathrm{k}_{17}=1.81 \times 10^{-4} \\
& \mathrm{k}_{18}=9.48 \times 10^{-15} \\
& \mathrm{k}_{19}=4.40 \times 10^{-11}\left(\mathrm{k}_{\infty}\right) \\
& \mathrm{k}_{20}{ }^{\mathrm{b}}=3.35 \times 10^{-11} \\
& \mathrm{k}_{21}{ }^{\mathrm{c}}=8.90 \times 10^{-12} \\
& \mathrm{k}_{22}{ }^{\mathrm{c}}=7.00 \times 10^{4} \\
& \mathrm{k}_{23}{ }^{\mathrm{c}}=8.90 \times 10^{-12} \\
& \mathrm{k}_{24}{ }^{\mathrm{c}}=7.00 \times 10^{4}
\end{aligned}
$$




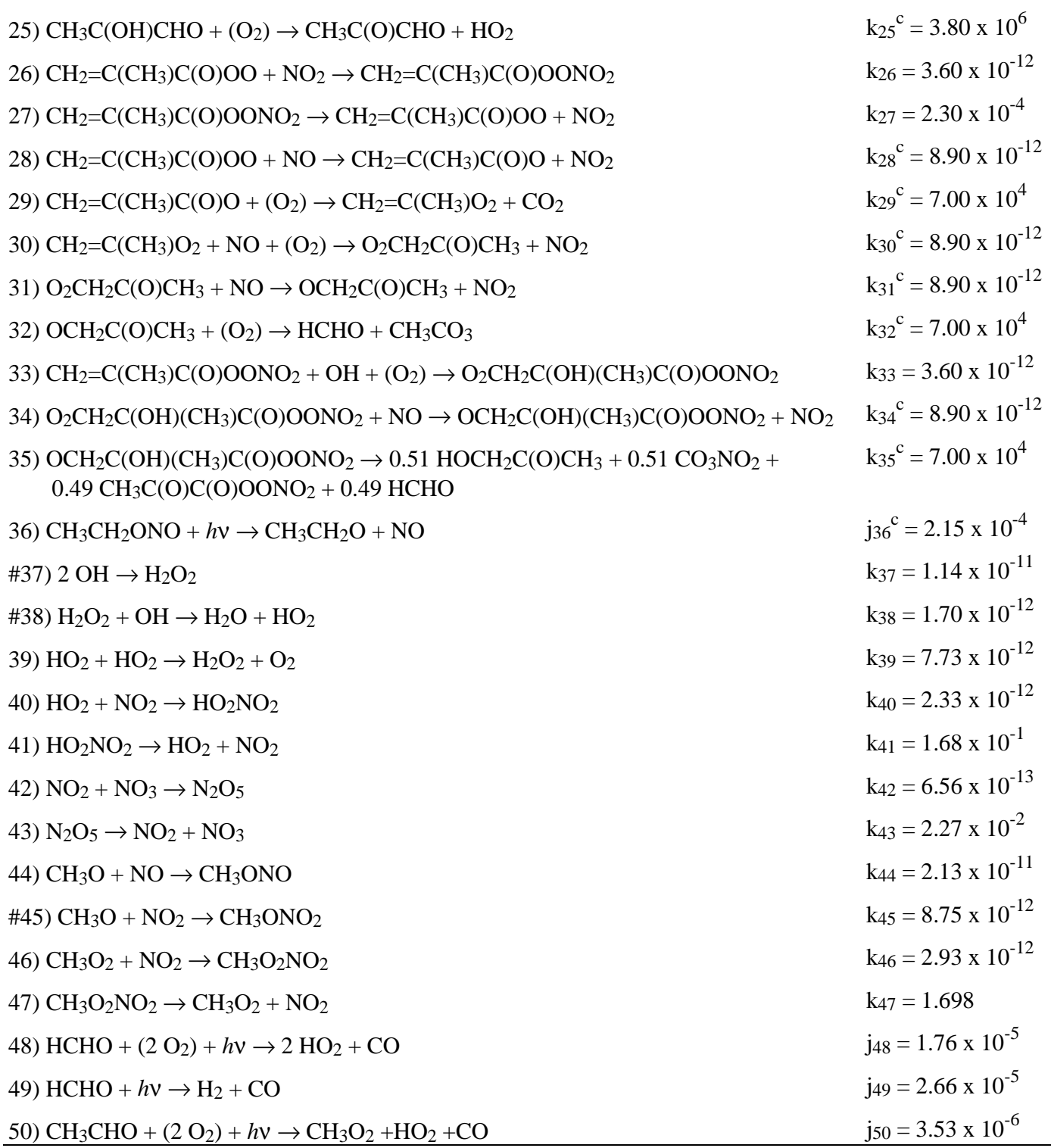

with similar compounds ${ }^{35}$ when there was no available information. As photochemical reaction rates are dependent on the experimental conditions and were not reported by Tuazon and Atkinson ${ }^{26}$ they were estimated on the basis of the methacrolein photooxidation experimental data ${ }^{26}$.

\section{Methodology}

As usual, the chemical process can be described by a system of kinetic differential equations,

$$
\frac{\partial c(t)}{\partial t}=f(k, c(t))
$$

where $c(t)$ is the $\mathrm{n}$-vector of species concentrations with $c(t$ $=0)=c^{0}$ and $k$ is the m-vector of kinetic parameters. For complex systems a numerical solution is required. The available methods to solve the differential equations and to investigate the main features of the mechanism are fully discussed in the literature ${ }^{19,24,25,36-38}$.

In investigating a chemical mechanism, it is important to assess the effects of parameter uncertainties on the predicted concentrations of the various intermediate and product species. This analysis is known as sensitivity analysis and is useful in determining the main reaction path. An element of the first order local concentration sensitivity matrix, $S_{i j}$ is given by

$$
S_{i j}\left(k^{0}, c^{0}, t_{1}, t_{2}\right)=\frac{\partial c_{i}\left(t_{2}\right)}{\partial k_{j}}
$$

and is the linear approximation of concentration change of species $i$ at the time $t_{2}$ caused by the differential change of 
the parameter of reaction $j$ at time $t_{l}$ from value $k_{j}^{0}$ to $k_{j}$. In this work the parameters are the photochemical coefficients and the thermal rate constants.

Sensitivity coefficients are normalized in order to eliminate their dependence on the dimensions of the kinetic model. The parameter-concentration interdependence may be described in two ways: by the overall sensitivities, which are the sum of the squares of the normalized sensitivities, and by the principal component analysis of the normalized sensitivity matrix. The overall sensitivities give the effect of a single parameter on a concentration group. The principal component analysis consists in the identification of the parameters group which has joint influence on a concentration group. This method is a kind of factor analysis and its main goal is to decry those hidden factors which have generated the dependence or variation in responses.

The eigenvectors of the matrix $S^{T} S$, where $S$ is the array of sensitivity coefficients, identify parameter groups while the eigenvalues give information about the effectiveness of these parameter groups for the change of species concentrations. A parameter is considered important if it belongs to a large element of an eigenvector corresponding to a large eigenvalue. The $t^{\text {th }}$ principal component of the system is the linear compound

$$
\Psi_{\ell}=a_{1 \ell} X_{1}+\ldots+a_{p 1} X_{p}
$$

whose coefficients $a_{p} \iota$ are the characteristic vector elements associated with the $l$ eigenvalue. The importance and usefulness of the component would be measured by the total variance magnitude attributable to it, that is by the ratio of its eigenvalue $\lambda_{l}$ to the sum of all eigenvalue.

An alternative way and more classical method for the investigation of the reactions relevance is the rate of production analysis called ROPA ${ }^{38,39}$. This method calculates the contribution of each reaction step to the total production rate of each species using concentration data and the rate coefficients. Although very simple to implement, this method gives results which are rather difficult to interpret in a correct way and sometimes leads to misleading conclusions. Thus, the combination of species reduction and rate sensitivity analysis ${ }^{25}$ seems to be a more effective way for this purpose, the rate of production analysis is a classic method for the identification of important reaction pathways. This methodology requires the calculation of the Pij matrix elements ${ }^{40,41}$, which show the contribution of reaction $\mathrm{j}$ to the rate of production of species $\mathrm{i}$.

\section{Results and Discussions}

The full mechanism and rate constants are presented in Table 1. The reduced mechanism was obtained after elimination of the unimportant reactions (denoted by \# in Table 1) on the basis of the principal component analysis described below. The rank of reactions ordered by overall sensitivities and rates is shown in Table 2. We calculated normalized sensitivities for all species at time points 1.9, $6.9,11.9,15.9,19.9,24.9$ and $40.9 \mathrm{~min}$. Eigenvalues of $S^{T} S$ and the corresponding eigenvectors are listed in Table 3.

In the conditions of the modeling, the main source of hydroxyl radicals is the reaction (5) $\left(\mathrm{HO}_{2}+\mathrm{NO} \rightarrow \mathrm{OH}+\right.$ $\mathrm{NO}_{2}$ ) which follows the photolysis of the ethyl nitrite $\left(\mathrm{CH}_{3} \mathrm{CH}_{2} \mathrm{ONO}+h \mathrm{v} \rightarrow \mathrm{CH}_{3} \mathrm{CH}_{2} \mathrm{O}+\mathrm{NO}\right)$ and the oxidation of the $\mathrm{CH}_{3} \mathrm{CH}_{2} \mathrm{O}$ radicals $\left(\mathrm{CH}_{3} \mathrm{CH}_{2} \mathrm{O}+\mathrm{O}_{2} \rightarrow \mathrm{CH}_{3} \mathrm{CHO}+\right.$ $\mathrm{HO}_{2}$ ). Reaction (5) accounts for $c a .95 \%$ of $\mathrm{OH}$ radical formed and the only significant sources of $\mathrm{NO}$ are the photodecomposition of ethyl nitrite $(7 \%)$ and $\mathrm{NO}_{2}(93 \%)$, reactions (36) and (10), respectively. Since photolysis light intensities during the experiments were not reported ${ }^{26}$, the ethyl nitrite photodecomposition coefficient was estimated from the experimental concentration profiles of MTA as a function of time (Fig. 1). This method of parameter estimation is supported by the facts discussed above: in the smog chamber conditions, the only significant source of hydroxyl radicals is ethyl nitrite phololysis and MTA reacts primarily with $\mathrm{OH}$ radicals. The selected values gave consistent results for other photodecompositions and are also in agreement with the value reported in literature ${ }^{42}$ for $\mathrm{NO}_{2}$ in the same experimental conditions. The set of reactions (Table 1) accounts for the MTA photooxidation in good agreement with experimental data (Fig. 1). As presented in Fig. 2, simulated results for the formation of the main products where hydroxyacetone and methylglyoxal show a good agreement with experimental data. On the other hand, formaldehyde and peroxymethacryloyl nitrate (Figs. 3 and 4), show a slight deviation mainly for longer times.

In these simulation conditions, formaldehyde is formed both from acetaldehyde, the initial product of ethyl nitrite photolysis, reaction (36), and by the sequence of reactions initiated by $\mathrm{OH}$ radical oxidation of MTA, reaction (20):

$\mathrm{CH}_{2}=\mathrm{C}\left(\mathrm{CH}_{3}\right) \mathrm{CHO}+\mathrm{OH}+\left(\mathrm{O}_{2}\right) \rightarrow 0.42$ $\mathrm{HOCH}_{2} \mathrm{C}\left(\mathrm{O}_{2}\right)\left(\mathrm{CH}_{3}\right) \mathrm{CHO}+0.08 \mathrm{O}_{2} \mathrm{CH}_{2} \mathrm{C}(\mathrm{OH})\left(\mathrm{CH}_{3}\right) \mathrm{CHO}$ $+0.50 \mathrm{CH}_{2}=\mathrm{C}\left(\mathrm{CH}_{3}\right) \mathrm{C}(\mathrm{O}) \mathrm{OO}+0.50 \mathrm{H}_{2} \mathrm{O}$

The rate of production analysis shows that $52.5 \%$ of formaldehyde is formed initially through the reaction sequence (20), (28), (29), (30), (31) and (32), 25.4\% through the reaction (13), $\mathrm{CH}_{3} \mathrm{O}+\left(\mathrm{O}_{2}\right) \rightarrow \mathrm{HCHO}+\mathrm{HO}_{2}$, and $22.1 \%$ through the reaction sequence (20), (23) and (24), which involve the reaction of $\mathrm{O}_{2} \mathrm{CH}_{2} \mathrm{C}(\mathrm{OH})\left(\mathrm{CH}_{3}\right) \mathrm{CHO}$ with NO. The $\mathrm{CH}_{3} \mathrm{O}$ radical is formed through reactions (15) and (14) from $\mathrm{CH}_{3} \mathrm{CO}_{3}$ which is a secondary product of MTA oxidation, see reaction (32), and a product of acetaldehyde photooxidation, reaction (12). For longer times, $t>10 \mathrm{~min}$, the relative importance of these paths is changed and $80.9 \%$ of formaldehyde is formed through the reaction sequence (20), (23) and (24), 10.0\% through the reaction sequence (20), (28), (29), (30), (31) and (32), and $9.1 \%$ through the reaction (13), $\mathrm{CH}_{3} \mathrm{O}+\left(\mathrm{O}_{2}\right) \rightarrow \mathrm{HCHO}+$ 
Table 2. Rank of reactions by overall sensitivity and rates.

\begin{tabular}{|c|c|c|c|c|c|c|c|c|c|}
\hline Rank & Reaction & $\begin{array}{l}\text { Overall } \\
\text { Sens.* }\end{array}$ & Reaction & Rates** & Rank & Reaction & $\begin{array}{l}\text { Overall } \\
\text { Sens.* }\end{array}$ & Reaction & Rates** \\
\hline 1 & 36 & $1.01 \times 10^{3}$ & 42 & $1.05 \times 10^{12}$ & 27 & 24 & 7.00 & 11 & $1.42 \times 10^{9}$ \\
\hline 2 & 20 & $1.83 \times 10^{2}$ & 43 & $1.02 \times 10^{12}$ & 28 & 23 & 7.00 & 33 & $8.25 \times 10^{8}$ \\
\hline 3 & 4 & $1.44 \times 10^{2}$ & 10 & $4.25 \times 10^{11}$ & 29 & 34 & 7.00 & 34 & $8.25 \times 10^{8}$ \\
\hline 4 & 5 & $9.47 \times 10^{1}$ & 6 & $2.60 \times 10^{11}$ & 30 & 21 & 7.00 & 35 & $8.25 \times 10^{8}$ \\
\hline 5 & 26 & $6.86 \times 10^{1}$ & 8 & $1.50 \times 10^{11}$ & 31 & 39 & 6.78 & 49 & $6.98 \times 10^{8}$ \\
\hline 6 & 28 & $6.31 \times 10^{1}$ & 7 & $1.28 \times 10^{11}$ & 32 & 46 & 6.74 & 48 & $4.62 \times 10^{8}$ \\
\hline 7 & 10 & $4.14 \times 10^{1}$ & 46 & $4.54 \times 10^{10}$ & 33 & 47 & 6.74 & 14 & $3.69 \times 10^{8}$ \\
\hline 8 & 40 & $3.95 \times 10^{1}$ & 47 & $4.54 \times 10^{10}$ & 34 & 12 & 6.44 & 13 & $3.62 \times 10^{8}$ \\
\hline 9 & 33 & $2.65 \times 10^{1}$ & 5 & $4.11 \times 10^{10}$ & 35 & 42 & 5.95 & 50 & $2.95 \times 10^{8}$ \\
\hline 10 & 16 & $2.63 \times 10^{1}$ & 36 & $3.00 \times 10^{10}$ & 36 & 50 & 4.07 & 9 & $2.41 \times 10^{8}$ \\
\hline 11 & 6 & $2.57 \times 10^{1}$ & 18 & $3.00 \times 10^{10}$ & 37 & 43 & 3.69 & 29 & $1.62 \times 10^{8}$ \\
\hline 12 & 15 & $2.26 \times 10^{1}$ & 20 & $2.40 \times 10^{10}$ & 38 & 27 & 1.75 & 28 & $1.62 \times 10^{8}$ \\
\hline 13 & 9 & $1.92 \times 10^{1}$ & 26 & $2.12 \times 10^{10}$ & 39 & 48 & $7.18 \times 10^{-1}$ & 30 & $1.62 \times 10^{8}$ \\
\hline 14 & 3 & $1.52 \times 10^{1}$ & 41 & $1.16 \times 10^{10}$ & 40 & 17 & $4.24 \times 10^{-1}$ & 32 & $1.62 \times 10^{8}$ \\
\hline 15 & 14 & $1.35 \times 10^{1}$ & 40 & $1.16 \times 10^{10}$ & 41 & 11 & $4.05 \times 10^{-1}$ & 31 & $1.62 \times 10^{8}$ \\
\hline 16 & 8 & $1.13 \times 10^{1}$ & 16 & $1.06 \times 10^{10}$ & 42 & 44 & $1.68 \times 10^{-1}$ & 15 & $9.04 \times 10^{7}$ \\
\hline 17 & 7 & 8.34 & 22 & $1.01 \times 10^{10}$ & 43 & 19 & $9.66 \times 10^{-2}$ & 2 & $2.97 \times 10^{7}$ \\
\hline 18 & 13 & 7.19 & 21 & $1.01 \times 10^{10}$ & 44 & 45 & $3.45 \times 10^{-2}$ & 3 & $1.95 \times 10^{7}$ \\
\hline 19 & 41 & 7.18 & 27 & $9.36 \times 10^{9}$ & 45 & 1 & $2.00 \times 10^{-2}$ & 38 & $1.18 \times 10^{7}$ \\
\hline 20 & 18 & 7.06 & 4 & $7.53 \times 10^{9}$ & 46 & 49 & $5.56 \times 10^{-3}$ & 45 & $6.88 \times 10^{6}$ \\
\hline 21 & 29 & 7.00 & 12 & $7.43 \times 10^{9}$ & 47 & 37 & $2.36 \times 10^{-4}$ & 1 & $4.02 \times 10^{6}$ \\
\hline 22 & 32 & 7.00 & 17 & $3.11 \times 10^{9}$ & 48 & 2 & $1.38 \times 10^{-4}$ & 19 & $1.80 \times 10^{6}$ \\
\hline 23 & 30 & 7.00 & 39 & $1.99 \times 10^{9}$ & 49 & 38 & $4.48 \times 10^{-5}$ & 44 & $5.19 \times 10^{4}$ \\
\hline 24 & 25 & 7.00 & 23 & $1.92 \times 10^{9}$ & 50 & $* * *$ & & 37 & $3.62 \times 10^{2}$ \\
\hline 25 & 31 & 7.00 & 25 & $1.92 \times 10^{9}$ & \multirow{2}{*}{\multicolumn{5}{|c|}{$\begin{array}{l}* \text { undimensional. } * * \text { units in molecule, } \mathrm{cm}^{3} \text { and } \mathrm{s} . * * \text { Overall sensitivity } \\
\text { for reaction } 35 \text { was not calculated because of numerical convergence } \\
\text { problems. }\end{array}$}} \\
\hline 26 & 22 & 7.00 & 24 & $1.92 \times 10^{9}$ & & & & & \\
\hline
\end{tabular}

Table 3. Eigenvalues and eigenvectors for the mechanism of MTA photooxidation.

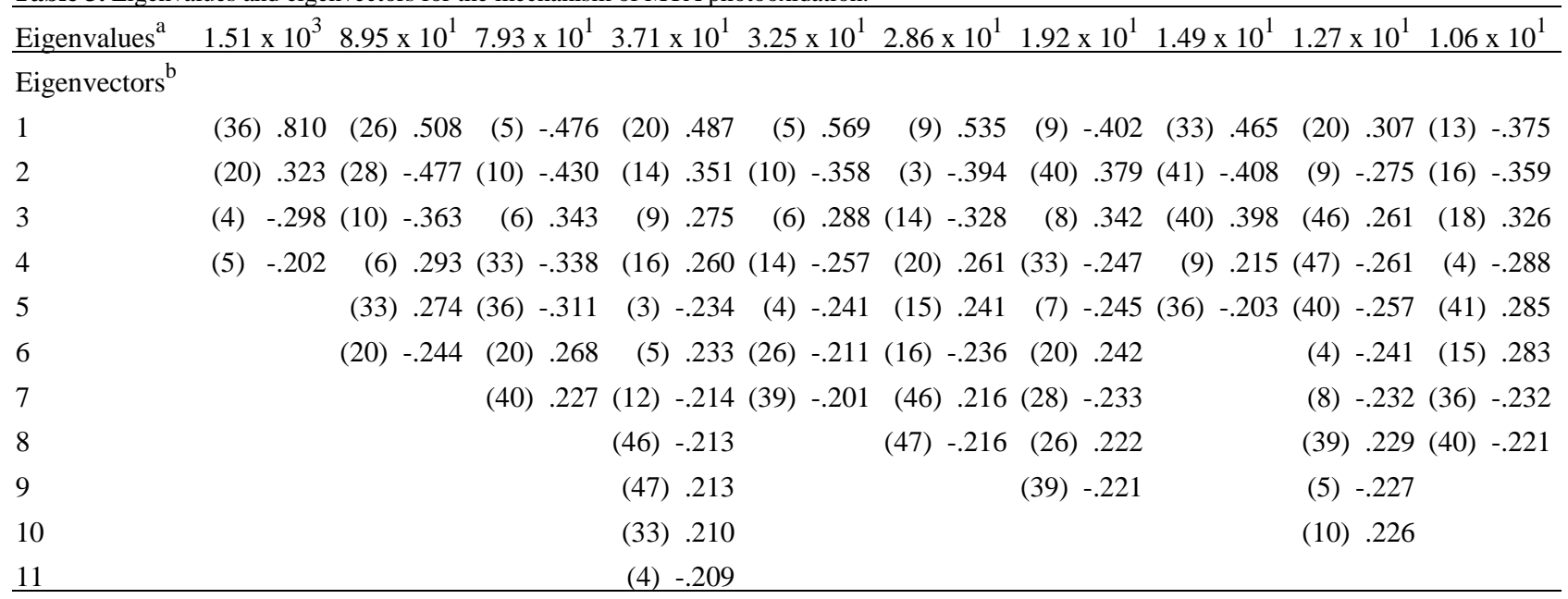




\begin{tabular}{|c|c|c|c|c|c|c|c|c|c|c|}
\hline Eigenvalues $^{\mathrm{a}}$ & 9.50 & 7.69 & 7.00 & 7.00 & 7.00 & 7.00 & 7.00 & 7.00 & 6.45 & 6.24 \\
\hline \multicolumn{11}{|l|}{ Eigenvectors ${ }^{b}$} \\
\hline 1 & (8) .491 & (18) -.400 & (23).- .522 & (32) -.685 & (30) .713 & (31) -.625 & (24) .734 & (21) -.629 & (18).- .409 & (42) .565 \\
\hline 2 & (7) -.334 & (13) -.380 & (25) .451 & (22) .445 & $(31)-.474$ & (29) .548 & (25) -.676 & (23) .565 & (15) .401 & (43).- .458 \\
\hline 3 & (41) .314 & (25) -.321 & (22).- .407 & 415 & (29).- .402 & (22).- .385 & & (22).- .411 & (13).- .365 & (18) .258 \\
\hline 4 & (13) .276 & (22) -.321 & (32).- .372 & (21) -.304 & - (22) .214 & (21) .319 & & (24) . .251 & (12) -.293 & (23) -.222 \\
\hline 5 & (10) -.236 & (24) -.321 & (24) .344 & (30) .223 & & & & (25) . 223 & (4) .244 & (21) -.221 \\
\hline 6 & (4) .212 & (29) -.222 & (30) .255 & & & & & & (9) -.243 & (4) .204 \\
\hline 7 & (42) .212 & (32) -.222 & & & & & & & 203 & (8) -.202 \\
\hline 8 & (16) .205) & (9) .219 & & & & & & & & \\
\hline 9 & & (50) .210 & & & & & & & & \\
\hline 10 & & (42) .201 & & & & & & & & \\
\hline Eigenvalues $^{\mathrm{a}}$ & 5.68 & 5.46 & 4.57 & 4.19 & 3.86 & 3.36 & 2.62 & 1.94 & 1.63 & 1.22 \\
\hline \multicolumn{11}{|l|}{ Eigenvectors $^{b}$} \\
\hline 1 & (18) -.636 & (34) .739 & (14) -.399 & (28) .389 & (12) .440 & (26) -.520 & (34) .405 & (33) -.400 & (50).- .433 & (3) .506 \\
\hline 2 & (16).- .313 & (4) -.273 & (46).- .393 & (26) .377 & (15).- .421 & (28) -.497 & (21) .354 & (31) -.361 & (15) .424 & (39) .431 \\
\hline 3 & (13) .294 & & (47) .393 & (16) -.311 & (3) -.315 & (16) -.346 & (23) .354 & (30).- .361 & (16) .387 & (20) .341 \\
\hline 4 & (4) -.270 & & (13) .351 & (14) .271 & (9) -.289 & (50) -.210 & (14) .292 & (28) -.299 & (12) .303 & (4) .330 \\
\hline 5 & (42) .256 & & (34) .315 & (50).- .242 & (50) .250 & & (39) -.260 & (29) -.296 & (41) -.260 & (41).- .244 \\
\hline 6 & (50).- .239 & & (15) .305 & (21) -.232 & (14) -.246 & & (29) -.243 & (32) -.296 & (3) -.258 & (5) .235 \\
\hline 7 & (43) -.213 & & & (23).- .232 & (20) .221 & & (32) -.243 & (3) .244 & (4) -.223 & (33) .218 \\
\hline Eigenvalues $^{\mathrm{a}}$ & 1.05 & $9.57 \times 10^{-1}$ & $5.93 \times 10^{-1}$ & $4.71 \times 10^{-1}$ & $2.10 \times 10^{-1}$ & $7.94 \times 10^{-2}$ & $4.46 \times 10^{-2}$ & $3.28 \times 10^{-2}$ & $2.91 \times 10^{-2}$ & $1.52 \times 10^{-2}$ \\
\hline \multicolumn{11}{|l|}{ Eigenvectors $^{b}$} \\
\hline 1 & (39) -.668 & 492 & (6) -.395 & (27) -.795 & (7) .424 & (43) -.714 & (17) -.832 & (11) -.803 & (7) -.497 & (44) .756 \\
\hline 2 & (12) .316 & (50) .487 & (40) .393 & (41).- .289 & (6) -.413 & (42).- .551 & (48).- .310 & (49).- .308 & (8).- .424 & (17).- .426 \\
\hline 3 & (5).- .309 & (13) .332 & (7) .367 & (40).- .286 & ) .365 & & (44).- .229 & (48) -.202 & (6).- .407 & (19) .363 \\
\hline 4 & (3) .268 & (14) .323 & (41) .330 & (50) .221 & (10).- .349 & & (19) -.201 & & (10) -.397 & (11) -.218 \\
\hline 5 & (50) -.264 & (15) .310 & (27).- .324 & & (8) .308 & & & & (43) -.278 & \\
\hline 6 & (40) -.248 & (33) .210 & (50).- .225 & & (41) -.288 & & & & (11) -.257 & \\
\hline 7 & & (16) .207 & & & (40) -.251 & & & & (42) -.225 & \\
\hline
\end{tabular}
Eigenvalues $^{\mathrm{a}} \quad 6.86 \times 10^{-3} 1.27 \times 10^{-3} 5.16 \times 10^{-4} 2.93 \times 10^{-4} 1.55 \times 10^{-4} 5.64 \times 10^{-5} 7.39 \times 10^{-6} 5.64 \times 10^{-6} 9.17 \times 10^{-7}$ Eigenvectors $\mathrm{b}$

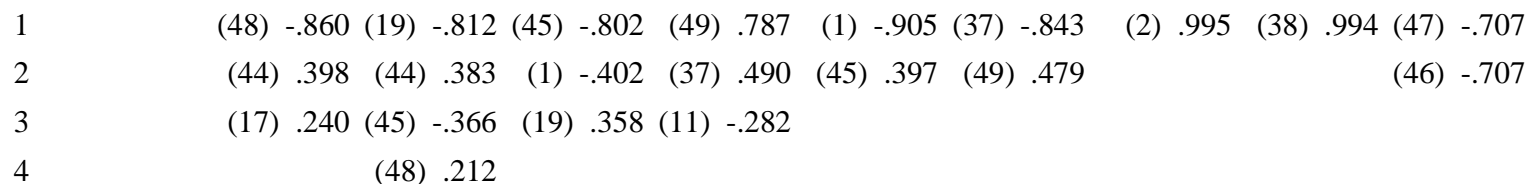

${ }^{a}$ Each column represents a principal component, that is a group of coupled reactions. The eigenvalues indicate the effectiveness of each group in changing the modeling results.

${ }^{\mathrm{b}}$ First entry refers to the rate constant for the reaction listed in Table 1 and second entry lists eigenvector components. The eigenvectors give the relative importance of each reaction in the group.

$\mathrm{HO}_{2}$. Under the modelling conditions, the decomposition reactions of formaldehyde, reactions (11), (49) and (48), are initially $11 \%$ of the total and after this the yield increases up to $45 \%$ at the end of reaction. As observed experimentally $^{26,42}$, the formed formaldehyde reacts essentially with $\mathrm{OH}$ radicals which are in relatively high concentrations (calculated values about 0.6-1.3 x $10^{7}$ molecule $\mathrm{cm}^{-3}$ ). In comparison with the $\mathrm{OH}$ radical reaction (11) $(\mathrm{HCHO}+$ $\left.\mathrm{OH}+\left(\mathrm{O}_{2}\right) \rightarrow \mathrm{HO}_{2}+\mathrm{CO}+\mathrm{H}_{2} \mathrm{O}\right)$, the photochemical decompositions (39) and (40) $\left(\mathrm{HCHO}+\left(2 \mathrm{O}_{2}\right)+h v \rightarrow 2\right.$ $\mathrm{HO}_{2}+\mathrm{CO}$ and $\mathrm{HCHO}+h v \rightarrow \mathrm{H}_{2}+\mathrm{CO}$ ) are of non-negligible importance (30-40\%). 


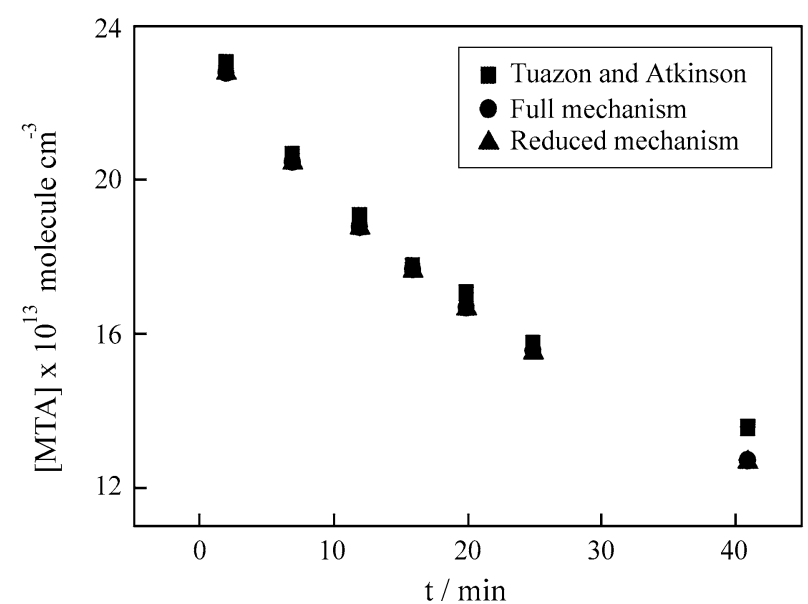

Figure 1. Simulated and experimental data for the oxidation of the MTA as a function of reaction time.

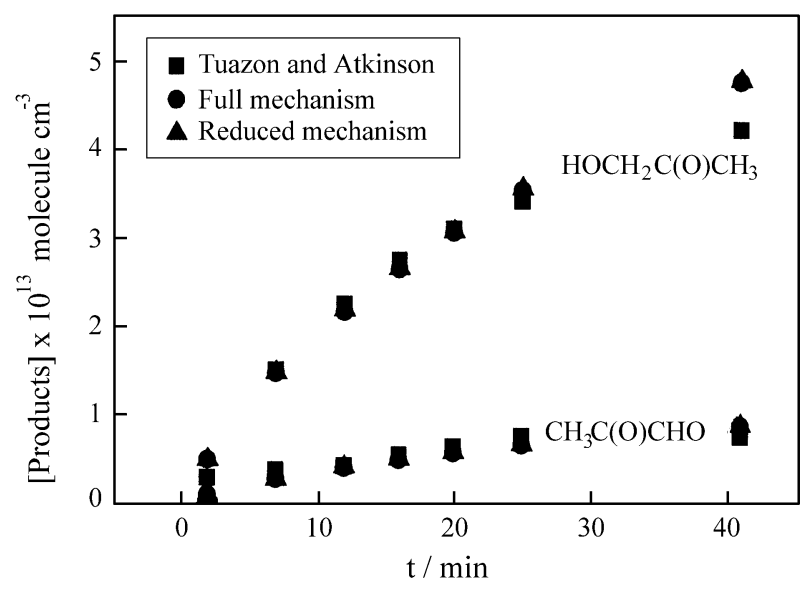

Figure 2. Simulated and experimental data for the main products of the gas-phase reactions of MTA with the $\mathrm{OH}$ radical in the presence of $\mathrm{NO}_{\mathrm{x}}$ as a function of reaction time.

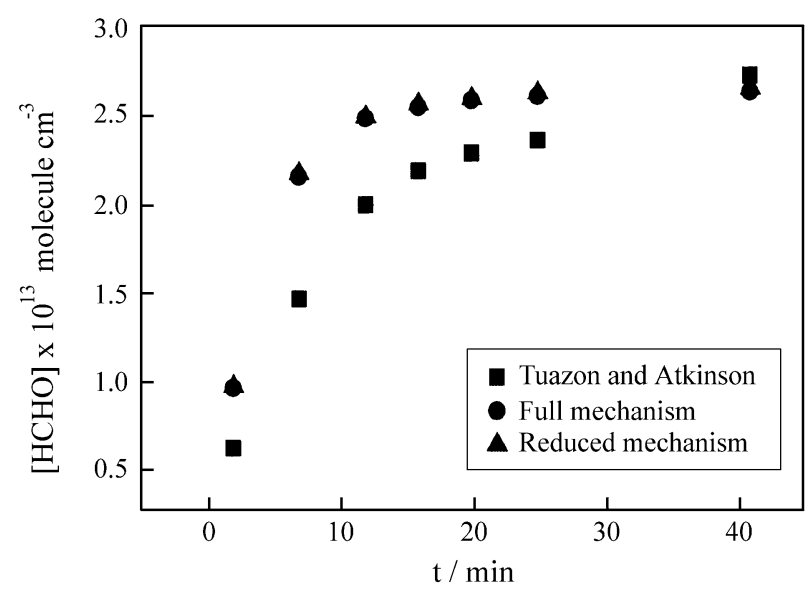

Figure 3. Simulated and experimental data for formaldehyde concentration as a function of reaction time.

In the conditions of this simulation, the formation of acetaldehyde and peroxyacetyl nitrate (PAN) can be attrib-

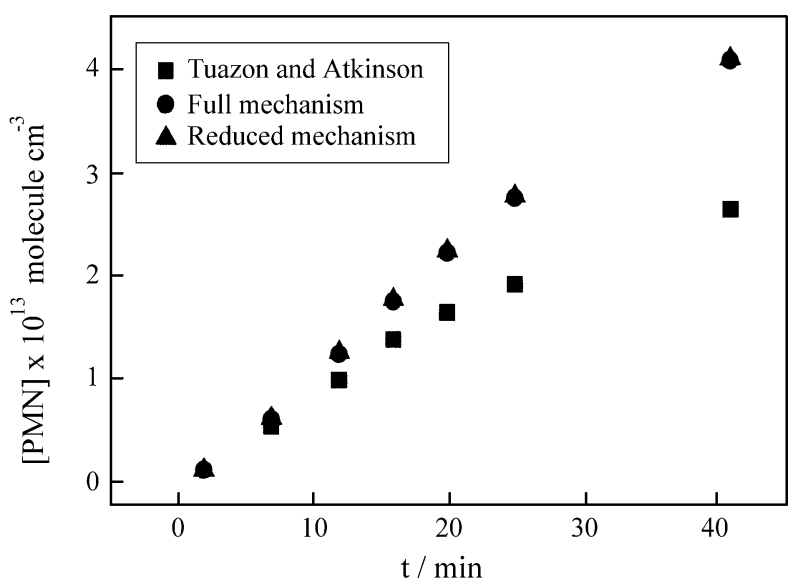

Figure 4. Simulated and experimental data for the peroxymethacryloyl nitrate $(\mathrm{PMN})$ concentrations as a function of reaction time.

uted to the photooxidation of ethyl nitrite ${ }^{26,42}$. In comparison with $\mathrm{OH}$ radical reaction $\left(\mathrm{CH}_{3} \mathrm{CHO}+\mathrm{OH}+\left(\mathrm{O}_{2}\right) \rightarrow\right.$ $\mathrm{CH}_{3} \mathrm{CO}_{3}+\mathrm{H}_{2} \mathrm{O}$ ), the acetaldehyde photochemical decompositions $\left(\mathrm{CH}_{3} \mathrm{CHO}+\left(2 \mathrm{O}_{2}\right)+h v \rightarrow \mathrm{CH}_{3} \mathrm{O}_{2}+\mathrm{HO}_{2}+\mathrm{CO}\right)$ are of non-negligible importance, as shown by the principal component analysis.

The $1^{\text {st }}$ and $2^{\text {nd }}$ principal components in Table 3 show that ethyl nitrite photodecomposition, reaction (36), oxidation of MTA, reaction (20), and $\mathrm{OH} / \mathrm{NO}$ chemistry, reactions (4) and (5), are strongly coupled and are the most influential reaction sequence in the mechanism. Thus, a small deviation in $\mathrm{k}_{20}$ or $\mathrm{j}_{36}$ should largely affect the simulation results. The same conclusions were obtained in the simulation of methyl-tert-butyl ether (MTBE) ${ }^{43}$ and methyl vinyl ketone (MVK) ${ }^{44}$ photooxidation by $\mathrm{OH}$ radicals.

According to the magnitude of the eigenvalues and significant entries $(\geq 0.20)$ of the corresponding eigenvector, the individual reactions may be classified in three groups:

1) Eigenvalues $\lambda_{1}$ to $\lambda_{31}$ are much larger than the remaining ones. Note that $\sum_{i=1}^{31} \lambda_{i} / \sum_{j=1}^{49} \lambda_{j}=0.9987$. Principal components $\psi_{1}$ to $\psi_{31}$ contain steps (3)-(10), (12)-(16), (18), (20)-(26), (28)-(36), (39)-(43), (46)-(47) and (50), forming the "basic" part of mechanism. According to $\psi_{1}$, the most influential reaction sequence is formed by (36), (20), (4) and (5). This first component emphasizes that the largest effect is brought about by setting the parameters $\mathrm{j}_{36}$ and $\mathrm{k}_{20}$. Reactions (4) and (5) largely affect the $\mathrm{NO} / \mathrm{NO}_{2}$ ratio and the simulated results. Due to the coupling of the individual reactions, this ratio not only depends on the rate of reactions (20) and (36) but also on all the reactions involving $\mathrm{NO}_{\mathrm{x}}$. Since $\mathrm{j}_{36}$ is an estimated parameter, some deviations of the simulated results may be attributed to it. An uncertainty analysis of this parameter shows 
that a change of $10 \%$ in $\mathrm{j}_{36}$ leads to a substantial change of all product concentrations $(4.8 \%$ in hydroxyacetone, $4.4 \%$ in methylglioxal, $5.9 \%$ in peroxymethacryloyl nitrate and $7.3 \%$ in formaldehyde). The inclusion of another minor path of reaction, such the formation of alkylnitrates, might affect the $\mathrm{NO} / \mathrm{NO}_{\mathrm{x}}$ ratios in a non-negligible amount.

2) According $\psi_{32}$ to $\psi_{39}$, reactions (11), (17), (19), (27), (44) and (48)-(49), are of "transitional" importance. As it will be shown, in spite of their small contributions they can not be removed from the mechanism.

3) Reactions (1), (2), (37)-(38) and (45) contained in $\psi_{40}$ to $\psi_{49}$ with eigenvalues below $2.66 \times 10^{-2}$ are unimportant and can be eliminated.

As shown in Table 4, eliminating the last group of reactions causes small changes in concentrations. However, additional elimination of steps (11), (17), (19), (27), (44) and (48)-(49) (i.e. reactions of "transitional" importance) leads to large deviations (Table 4). Since all concentration changes should be small, no further mechanism reduction is possible.

The rank of reactions by overall sensitivity (Table 2) suggests that reaction 49 may be eliminated. However, this elimination leads to large deviations (e. $g$. at $\mathrm{t}=40.9 \mathrm{~min}$ the deviation for $\mathrm{HCHO}$ is $5.9 \%$ ). The rate reaction rank (Table 2) gives a different rank of reactions and is not an effective way of reducing a mechanism. Individual rates do not consider the interactions between reactions and may lead to incorrect conclusions about the relevance of individual reactions. Anyway, the rate of production analysis is a good method for the exploration of the reaction pathways and provides useful information as shown in the initial part of this discussion.

\section{Conclusions}

The proposed chemical mechanism gives satisfactory results for the oxidation of MTA by $\mathrm{OH}$ radicals in comparison with experimental chamber data. Unfortunately the experimental data were obtained for a rather narrow range

Table 4. Comparison of concentration deviations from full mechanism, eliminating of steps (1), (2), (37), (38) and (45) (column A) and also steps (11), (17), (44), (48) and (49) (column B).

\begin{tabular}{lrc} 
& \multicolumn{2}{c}{ Deviations (\%) } \\
\cline { 2 - 3 } Compounds & $\mathrm{A}$ & $\mathrm{B}$ \\
\hline MTA & -0.34 & 0.64 \\
Hydroxyacetone & 0.39 & -0.74 \\
Methylglyoxal & 0.38 & -0.73 \\
Formaldehyde & 0.49 & 25.85 \\
PMN & 0.51 & -0.57 \\
$\mathrm{NO}$ & -1.50 & 24.95 \\
$\mathrm{NO}_{2}$ & -0.75 & 9.86 \\
\hline
\end{tabular}

of conditions. Since mechanism results are a function of initial conditions, the conclusions taken from the eigenvalue-eigenvector analysis are only valid for this set of conditions. Anyway, the results shows that the reaction mechanism is strongly coupled and confirms that the most influential reactions are ethyl nitrite photolysis, the MTA oxidation, PAN and $\mathrm{HO}_{\mathrm{x}} / \mathrm{NO}_{\mathrm{x}}$ chemistry. This is in agreement with independent evidences that tropospheric chemistry is controlled by $\mathrm{NO}_{\mathrm{x}}$ concentrations and $\mathrm{OH}$ oxidation of volatile organic compounds.

On the basis of the calculated eigenvalues, the mechanism can be reduced to 45 reactions. Since reactions (21) (35) form the basic part of the mechanism, the estimation of their rate constants may lead to a considerable uncertainty in the simulated results. Then, further experiments with this system, in order to study those reaction paths, would be important in the improvement of atmospheric photochemical mechanisms.

\section{Acknowledgements}

The authors gratefully acknowledge CAPES and FAPERJ for partial financial support, NCE/UFRJ for computing facilities on the SP2 supercomputer, and Prof. T. Turányi (Central Research Institute for Chemistry, Budapest, Hungary) for a free copy of the KINAL package.

\section{Note}

All calculations were performed using the KINAL package $^{45}$.

\section{References}

1. Rasmussen, R.A. Environ. Sci. Technol. 1970, 4, 667.

2. Rasmussen, R.A. J. Air Pollut. Control Assoc. 1972, 22, 537 .

3. Tingey, D.T.; Manning, M.; Grothaus, L.C.; Burns, W.F. Physiol. Plants 1979, 47, 112.

4.Zimmerman, P.R. Determination of emission rates of hydrocarbons from indigenous species of vegetation in the Tampa/St. Petersburg FL, area, EPA-904/9-77$028,1979$.

5. Isidorov, V.A.; Zenkevich, I.G.; Ioffe, B.V. Atmos. Environ. 1985, 19, 1.

6. Lamb, B.; Westberg, H.; Allwine, G.; Quarles, T. J. Geophys. Res. 1985, 90, 2380.

7. Arnts, R.R.; Gay Jr., B.W. Photochemistry of some naturally emitted hydrocarbons, EPA-600 3-79-081, September, 1979.

8. Cox, R.A.; Derwent, R.G.; Williams, M.R. Environ. Sci. Technol. 1980, 14, 57.

9. Gu, C.L.; Rynard, C.M.; Hendry, D.G.; Mill, T. Environ. Sci. Technol. 1985, 19, 151.

10. Tuazon, E.C.; Atkinson, R. Int. J. Chem. Kinet. 1990, 22,1221 .

11. 
Kamens, R.M.; Gery, M.W.; Jeffries, H.E.; Jackson, M.; Cole, E.I. Int. J. Chem. Kinet. 1982, 14, 955.

12. Niki, H.; Maker, P.D.; Savage, C.M.; Breitenbach, L.P. Environ. Sci. Technol. 1983, 17, 312A.

13.Zimmerman, P.R.; Chatfield, R.B.; Fishman, J.; Crutzen, P.J.; Hanst, P.L. Geophys. Res. Lett. 1978, 5, 679.

14. Lamb, B.; Guenther, A.; Gay, D.; Westberg, H. Atmos. Environ. 1987, 21, 1695.

15.Zimmerman, P.R.; Greenberg, J.P.; Westberg, C.E. J. Geophys. Res. 1988, 93, 1047.

16. Lloyd, A.C.; Atkinson, R.; Lurmann, F.W.; Nitta, B. Atmos. Environ. 1983, 17, 1931.

17. Killus, J.P.; Whitten, G.Z. Environ. Sci. Technol. 1984, 18, 142.

18. Atkinson, R. Chem. Rev. 1986, 86, 69.

19. Vajda, S.; Valko, P.; Turányi, T. Int. J. Chem. Kinet. 1985, 17, 55.

20. Dickinson, R.P.; Gelinas, R.J. J. Comp. Phys. 1976, $21,123$.

21.Hwang, J.T.; Dougherty, E.P.; Rabitz, S.; Rabitz, H. J. Chem. Phys. 1978, 69, 5180.

22. Dougherty, E.P.; Hwang, J.T.; Rabitz, H. J. Chem. Phys. 1979, 71, 1794.

23. Edelson, D.; Allara, L. Int. J. Chem. Kinet. 1980,12, 605.

24. Turányi, T.; Bérces, T.; Vajda, S. Int. J. Chem. Kinet. 1989, 21, 83.

25. Turányi, T. J. Math. Chem. 1990, 5, 203.

26. Tuazon, E.C.; Atkinson, R. Int. J. Chem. Kinet. 1990 , 22,591 .

27. Atkinson, R. Atmos. Environ. 1990, 24A, 1.

28. Pimentel, A.S.; Arbilla, G. Química Nova 1997, 20, 252.

29. Carter, W.P.L. Atmos. Environ. 1990, 24A, 481.
30. Grosjean, D.; Williams II, E.L.; Grosjean, E. Int. J. Chem. Kinet. 1993, 25, 921.

31. Atkinson, R. J. Phys. Chem. Ref. Data 1989, Monograph n. 1, 1 .

32. Atkinson, R. J. Phys. Chem. Ref. Data 1994, Monograph n. 2, 1 .

33. Atkinson, R.; Baulch, D.L.; Cox, R.A.; Hampson Jr., R.F.; Kerr, J.A.; Troe, J.; J. Phys. Chem. Ref. Data 1992, 21, 1125 .

34. Atkinson, R.; Baulch, D.L.; Cox, R.A.; Hampson Jr., R.F.; Kerr, J.A.; Troe, J. J. Phys. Chem. Ref. Data 1989, $18,881$.

35. Atkinson, R. Int. J. Chem. Kinet. 1997, 29, 99.

36. Steinfeld, J.I.; Francisco, J.S.; Hase, W.L. Chemical Kinetics and Dynamics, Prentice-Hall, Englewood Cliffs, NJ, 1989.

37. Pilling, M.J. In: Modern Gas Kinetics, Pilling, M.J.; Smith, I.W.M., eds., Blackwell, Oxford, 1987.

38. Hirst, D.M. A Computational Approach to Chemistry, Blackwell Scientific Publications, Oxford, 1990.

39. Gelinas, R.J.; Science Applications, Inc., Preprint No AI/PL/C279, 1979.

40. Kee, R.J.,Grear, J.F., Smooke, M.D.; Miller, J.A. Sandia National Labs., SAND 85-8240, 1985.

41. Gardiner Jr., W.C. J. Phys. Chem. 1977, 81, 2367.

42. Carter, W.P.L.; Tuazon, E.C.; Ashmann, S.M. Investigation of the Atmospheric Chemistry of Methyl tertbutyl ether (MTBE), prepared for the Auto/Oil Air Quality Improvement Research Program, January, 1991.

43. Pimentel, A.S.; Arbilla, G. J. Braz. Chem. Soc. 1998, 9, 539.

44. Pimentel, A.S.; Arbilla, G. J. Braz. Chem. Soc. 1998, 9, 551

45. Turányi, T. Comp. Chem. 1990, 14, 253-254. 